\title{
Research on Innovation Performance Evaluation of Regional Industrial Enterprises above Scale based on Grey Relational Analysis
}

\author{
Shanshan Pei ,* \\ School of Cyberspace Security, Shan Dong University of Political science and Law, Jinan, China
}

\begin{abstract}
Scientific evaluation of innovation performance of Regional Industrial Enterprises above scale has an important impact on promoting the rapid development of Industrial Enterprises above scale. In this paper, the entropy weight method is used to determine the index weight, and the gray correlation analysis method is used to evaluate the innovation performance of Industrial Enterprises above regional scale. The results show that the innovation performance of Industrial Enterprises above scale is not balanced among regions, and the innovation performance of Industrial Enterprises above scale in Guangdong, Jiangsu, Zhejiang and other regions is relatively high; the innovation performance of Industrial Enterprises above scale in Ningxia, Hainan, Qinghai and other regions is relatively low, so it is necessary to further increase investment, allocate resources as a whole, and improve the innovation performance of Industrial Enterprises above scale New performance.
\end{abstract}

\section{Introduction}

Industry plays a leading role in the national economy and is an important pillar of regional economic development [1]. Since China took the new road of industrialization, the enterprise structure has been optimized, the overall scale has been significantly expanded, and the scale efficiency has been significant. In particular, the comprehensive economic benefits and profitability of China's Industrial Enterprises above designated size are steadily improving. The economic benefits and innovation ability of Industrial Enterprises above Designated Size directly affect the development level of China's industry and even the national economy. However, at the same time of rapid development, there are still problems such as lack of innovation in the development of China's Industrial Enterprises above designated size. The technological innovation ability and innovation efficiency of Industrial Enterprises above Designated Size directly affect the realization of the goal of building an innovative country in China. Under the current investment level, giving full play to the efficiency of innovation investment resources is conducive to alleviate the dilemma of serious shortage of innovation investment in China [2-3]. There are some differences in the basis of scientific and technological progress, input and output levels of scientific and technological activities of Industrial Enterprises above Designated Size in different regions. Therefore, we should objectively evaluate and find out the reasons for the regional differences in scientific and technological innovation ability of Industrial Enterprises above Designated Size in various cities, and put forward the countermeasures to quickly improve their scientific and technological innovation ability.
From the existing literature, there are relatively few discussions on the innovation performance evaluation of Industrial Enterprises above Designated Size, and the research on the evaluation from the regional perspective is even more rare; moreover, the index selection of most evaluation systems is relatively simple and lack of pertinence. The choice of evaluation methods is often subjective, which makes it difficult to evaluate the innovation performance level of Industrial Enterprises above the regional scale scientifically and effectively. Therefore, this paper applies the grey relational analysis method to establish the innovation performance evaluation model of Regional Industrial Enterprises above Designated Size, which sums up the innovation performance evaluation problem as a grey relational problem, and studies the innovation performance of Regional Industrial Enterprises above Designated Size by comparing the correlation degree of sequence and reference sequence, so as to provide reference for the innovation evaluation of Regional Industrial Enterprises above Designated Size and the formulation of relevant policies Improve the quality of reference.

\section{Research Method}

In this paper, the entropy weight method is used to determine the index weight, and the gray correlation analysis method is used to evaluate the innovation performance of Industrial Enterprises above regional scale.

\subsection{Entropy weight method}

Information entropy is a concept to describe the amount of

\footnotetext{
*Corresponding author: shan616@163.com
} 
information. In the process of financial performance evaluation index weighting, if the amount of information of an evaluation index is larger, it will be more important in decision-making. Therefore, information entropy can be used to measure the amount of information of each evaluation index, and then determine the weight of each rating index.

\subsection{Grey relation analysis}

A large amount of information in reality is not a white system with clear information or a black system without clear information, but a grey system. Using the grey system theory to study the economic system, instead of the purely qualitative description method in the past, we should make the problem concrete and quantitative, find out the law from the situation where the law is not obvious, and analyze and predict the law, which has a great guiding role in promoting the economic development [4-5].

The specific analysis process of grey correlation analysis is as follows:

(1) Determination of reference sequence

The reference sequence of dependent variable is determined as follows:

$$
X_{0}(k)=\left\{X_{0}(1), X_{0}(2), \cdots, X_{0}(n)\right\}, k=1,2, \cdots, n
$$

The comparison sequence of independent variables is determined as follows:

$$
X_{i}(k)=\left\{X_{i}(1), X_{i}(2), \cdots, X_{i}(n)\right\}, i=1,2, \cdots, m
$$

(2) Data dimensionless

According to the data characteristics of Industrial Enterprises above regional scale, this paper uses the initial value method to process the data.

$$
x_{i}(k)=X_{i}(k) / X_{i}(1)
$$

(3) Correlation coefficient

The calculation formula of grey correlation coefficient is as follows:

$$
\varepsilon_{i}(k)=\frac{\min _{i} \min _{j}\left|x_{0}(k)-x_{i}(k)\right|+\rho \max _{i} \max _{j}\left|x_{0}(k)-x_{i}(k)\right|}{\left|x_{0}(k)-x_{i}(k)\right|+\rho \max _{i} \max _{j}\left|x_{0}(k)-x_{i}(k)\right|}
$$

(4) Correlation degree

The calculation formula of grey correlation degree is as follows:

$$
r_{0 i}=\frac{1}{n} \sum_{k=1}^{n} \varepsilon_{i}(k)
$$

(5) Weighted correlation degree

According to the weight $W_{j}$ of each index, we can get the grey correlation degree $r_{0 i}^{\prime}$ of the $i$ scheme:

$$
r_{0 i}^{\prime}=\frac{1}{n} \sum_{k=1}^{n} W_{j} \varepsilon_{i}(k)
$$

\section{Data Source And Index Selection}

\subsection{Data sources}

This paper selects 30 provinces (cities, autonomous regions) in China to analyze the relevant data of Industrial Enterprises above designated size. The data comes from China Statistical Yearbook (2015-2019) and China Science and Technology Statistical Yearbook (2015-2019). Due to incomplete data, other regions have not included them.

\subsection{Index selection}

In order to objectively and comprehensively evaluate the innovation performance of Regional Industrial Enterprises above Designated Size, combined with the characteristics of Industrial Enterprises above Designated Size, this paper constructs the innovation performance evaluation index system of Regional Industrial Enterprises above designated size as shown in Table 1.

Table 1. Technological innovation performance evaluation index of regional industrial enterprises above designated size.

\begin{tabular}{|c|l|}
\hline Index number & Evaluating indicator \\
\hline $\mathrm{a}_{1}$ & Internal expenditure of R\&D funds \\
\hline $\mathrm{a}_{2}$ & Full time equivalent of R\&D personnel \\
\hline $\mathrm{a}_{3}$ & Expenditure on new product development \\
\hline $\mathrm{a}_{4}$ & New product sales revenue \\
\hline $\mathrm{a}_{5}$ & Number of invention patents \\
\hline $\mathrm{a}_{6}$ & Number of new product development projects \\
\hline
\end{tabular}

\section{Empirical Analysis}

According to the five index variables of innovation performance of 30 provincial high-tech industries in China, based on the relevant data of high-tech industries in 2018, this paper uses entropy weight method to determine the index weight, and uses grey correlation analysis method to evaluate and rank the level of innovation performance of regional high-tech industries.

\subsection{Determine index weight}

Firstly, the weight of innovation performance evaluation index of Industrial Enterprises above regional scale is determined.

(1) Calculate the information entropy of each index

On the basis of standardizing the index data, the information entropy of the index can be obtained as follows:

$E_{j}=(0.80,0.76,0.78,0.83,0.79,0.80)$

(2) Determine the weight of each index

The weight of performance evaluation index of Industrial Enterprises above regional scale is determined, as shown in Table 2 . 
Table 2. Index weight

\begin{tabular}{|c|l|l|}
\hline $\begin{array}{l}\text { Index } \\
\text { number }\end{array}$ & Evaluating indicator & weight \\
\hline $\mathrm{a}_{1}$ & Internal expenditure of R\&D funds & 0.16 \\
\hline $\mathrm{a}_{2}$ & $\begin{array}{l}\text { Full time equivalent of R\&D } \\
\text { personnel }\end{array}$ & 0.19 \\
\hline $\mathrm{a}_{3}$ & $\begin{array}{l}\text { Expenditure on new product } \\
\text { development }\end{array}$ & 0.18 \\
\hline $\mathrm{a}_{4}$ & New product sales revenue & 0.14 \\
\hline $\mathrm{a}_{5}$ & Number of invention patents & 0.17 \\
\hline $\mathrm{a}_{6}$ & $\begin{array}{l}\text { Number of new product } \\
\text { development projects }\end{array}$ & 0.16 \\
\hline
\end{tabular}

It can be seen from table 2 that the weights of innovation performance evaluation indexes of Industrial Enterprises above designated size are as follows:

$$
W=(0.16,0.19,0.18,0.14,0.17,0.16)
$$

\subsection{Grey relation analysis}

(1) Determine reference sequence

Because the innovation performance evaluation index

Table 3. Results of dimensionless treatment of index value

\begin{tabular}{|c|c|c|c|c|c|c|}
\hline Region & $\mathbf{a}_{1}$ & $a_{2}$ & $\mathbf{a}_{3}$ & $\mathbf{a}_{4}$ & a5 & $\mathbf{a}_{6}$ \\
\hline Beijing & 0.1051 & 0.1003 & 0.0906 & 0.1300 & 0.0755 & 0.1080 \\
\hline Tianjin & 0.0979 & 0.0477 & 0.0971 & 0.1200 & 0.0857 & 0.0641 \\
\hline Hebei & 0.1328 & 0.0586 & 0.0942 & 0.1813 & 0.1109 & 0.1158 \\
\hline Shanxi & 0.0493 & 0.0233 & 0.0322 & 0.0623 & 0.0438 & 0.0406 \\
\hline $\begin{array}{l}\text { Inner } \\
\text { Mongolia }\end{array}$ & 0.0261 & 0.0139 & 0.0139 & 0.0491 & 0.0254 & 0.0213 \\
\hline Liaoning & 0.1157 & 0.0524 & 0.0813 & 0.1427 & 0.0854 & 0.0918 \\
\hline Jilin & 0.0342 & 0.0127 & 0.0234 & 0.0273 & 0.0179 & 0.0323 \\
\hline Heilongjiang & 0.0143 & 0.0119 & 0.0250 & 0.0287 & 0.0211 & 0.0160 \\
\hline Shanghai & 0.2488 & 0.1212 & 0.1503 & 0.2633 & 0.1415 & 0.2265 \\
\hline Jiangsu & 0.7219 & 0.5405 & 0.6659 & 0.9608 & 0.7324 & 0.7397 \\
\hline Zhejiang & 0.5919 & 0.2705 & 0.7196 & 0.5445 & 0.6337 & 0.3806 \\
\hline Anhui & 0.2421 & 0.2529 & 0.2117 & 0.2360 & 0.1716 & 0.1712 \\
\hline Fujian & 0.1346 & 0.0952 & 0.1487 & 0.2491 & 0.1941 & 0.1488 \\
\hline Jiangxi & 0.1146 & 0.0504 & 0.1285 & 0.1271 & 0.1084 & 0.1101 \\
\hline Shandong & 0.3872 & 0.3027 & 0.3328 & 0.6732 & 0.3803 & 0.3479 \\
\hline Henan & 0.1953 & 0.0861 & 0.1336 & 0.2510 & 0.2059 & 0.1343 \\
\hline Hubei & 0.2251 & 0.1242 & 0.1265 & 0.2494 & 0.1689 & 0.1754 \\
\hline Hunan & 0.1934 & 0.1113 & 0.1236 & 0.2452 & 0.1653 & 0.1624 \\
\hline Guangdong & 1.0000 & 1.0000 & 1.0000 & 1.0000 & 1.0000 & 1.0000 \\
\hline Guangxi & 0.0466 & 0.0247 & 0.0283 & 0.0423 & 0.0277 & 0.0327 \\
\hline Hainan & 0.0027 & 0.0024 & 0.0058 & 0.0054 & 0.0032 & 0.0044 \\
\hline Chongqing & 0.1071 & 0.0599 & 0.1054 & 0.1420 & 0.0996 & 0.0927 \\
\hline Sichuan & 0.0908 & 0.1034 & 0.1149 & 0.1625 & 0.1252 & 0.1178 \\
\hline Guizhou & 0.0190 & 0.0252 & 0.0255 & 0.0362 & 0.0322 & 0.0221 \\
\hline Yunnan & 0.0236 & 0.0197 & 0.0341 & 0.0508 & 0.0387 & 0.0289 \\
\hline Shaanxi & 0.0516 & 0.0429 & 0.0502 & 0.1028 & 0.0632 & 0.0704 \\
\hline Gansu & 0.0070 & 0.0117 & 0.0105 & 0.0226 & 0.0129 & 0.0137 \\
\hline Qinghai & 0.0031 & 0.0031 & 0.0016 & 0.0032 & 0.0019 & 0.0026 \\
\hline Ningxia & 0.0123 & 0.0090 & 0.0111 & 0.0176 & 0.0114 & 0.0070 \\
\hline Xinjiang & 0.0110 & 0.0120 & 0.0077 & 0.0213 & 0.0093 & 0.0124 \\
\hline
\end{tabular}

of Industrial Enterprises above regional scale is a positive index, the maximum value of each index is selected as the reference sequence. Namely:

$X_{0}(k)=\{393760563,103499,121523,21072031,621950,33366963\}$

(2) Dimensionless index

The original index data of Industrial Enterprises above regional scale are standardized, and the dimensionless processing results are obtained, as shown in Table 3. 
(3) Grey correlation coefficient

According to formula 4, the grey correlation coefficient of Industrial Enterprises above regional scale can be obtained, as shown in Table 4.

Table 4. Grey correlation coefficient

\begin{tabular}{|l|c|c|c|c|c|c|}
\hline Region & $\mathbf{a}_{\mathbf{1}}$ & $\mathbf{a}_{\mathbf{2}}$ & $\mathbf{a}_{\mathbf{3}}$ & $\mathbf{a}_{\mathbf{4}}$ & $\mathbf{a}_{\mathbf{5}}$ & $\mathbf{a}_{\mathbf{6}}$ \\
\hline Beijing & 0.3581 & 0.3569 & 0.3544 & 0.3646 & 0.3506 & 0.3588 \\
\hline Tianjin & 0.3562 & 0.3439 & 0.3560 & 0.3619 & 0.3532 & 0.3478 \\
\hline Hebei & 0.3653 & 0.3465 & 0.3553 & 0.3788 & 0.3596 & 0.3608 \\
\hline Shanxi & 0.3443 & 0.3382 & 0.3403 & 0.3474 & 0.3430 & 0.3422 \\
\hline Inner Mongolia & 0.3389 & 0.3361 & 0.3361 & 0.3442 & 0.3387 & 0.3378 \\
\hline Liaoning & 0.3608 & 0.3450 & 0.3521 & 0.3680 & 0.3531 & 0.3547 \\
\hline Jilin & 0.3408 & 0.3358 & 0.3383 & 0.3391 & 0.3370 & 0.3403 \\
\hline Heilongjiang & 0.3362 & 0.3356 & 0.3386 & 0.3395 & 0.3377 & 0.3366 \\
\hline Shanghai & 0.3992 & 0.3623 & 0.3701 & 0.4039 & 0.3677 & 0.3922 \\
\hline Jiangsu & 0.6422 & 0.5207 & 0.5991 & 0.9271 & 0.6510 & 0.6573 \\
\hline Zhejiang & 0.5502 & 0.4063 & 0.6403 & 0.5229 & 0.5768 & 0.4463 \\
\hline Anhui & 0.3971 & 0.4005 & 0.3877 & 0.3952 & 0.3760 & 0.3759 \\
\hline Fujian & 0.3658 & 0.3555 & 0.3696 & 0.3993 & 0.3825 & 0.3697 \\
\hline Jiangxi & 0.3605 & 0.3446 & 0.3642 & 0.3638 & 0.3589 & 0.3594 \\
\hline Shandong & 0.4489 & 0.4172 & 0.4280 & 0.6043 & 0.4461 & 0.4336 \\
\hline Henan & 0.3828 & 0.3533 & 0.3655 & 0.3999 & 0.3860 & 0.3657 \\
\hline Hubei & 0.3918 & 0.3631 & 0.3637 & 0.3994 & 0.3752 & 0.3771 \\
\hline Hunan & 0.3823 & 0.3597 & 0.3629 & 0.3981 & 0.3742 & 0.3734 \\
\hline Guangdong & 1.0000 & 1.0000 & 1.0000 & 1.0000 & 1.0000 & 1.0000 \\
\hline Guangxi & 0.3437 & 0.3386 & 0.3394 & 0.3426 & 0.3392 & 0.3404 \\
\hline Hainan & 0.3336 & 0.3335 & 0.3343 & 0.3342 & 0.3337 & 0.3340 \\
\hline Chongqing & 0.3586 & 0.3468 & 0.3582 & 0.3678 & 0.3567 & 0.3549 \\
\hline Sichuan & 0.3545 & 0.3577 & 0.3606 & 0.3735 & 0.3633 & 0.3614 \\
\hline Guizhou & 0.3372 & 0.3387 & 0.3387 & 0.3412 & 0.3403 & 0.3380 \\
\hline Yunnan & 0.3383 & 0.3374 & 0.3407 & 0.3447 & 0.3418 & 0.3395 \\
\hline Shaanxi & 0.3449 & 0.3428 & 0.3445 & 0.3575 & 0.3476 & 0.3494 \\
\hline Gansu & 0.3345 & 0.3356 & 0.3353 & 0.3381 & 0.3359 & 0.3360 \\
\hline Qinghai & 0.3337 & 0.3337 & 0.3333 & 0.3337 & 0.3334 & 0.3336 \\
\hline Ningxia & 0.3357 & 0.3350 & 0.3355 & 0.3369 & 0.3355 & 0.3345 \\
\hline Xinjiang & 0.3354 & 0.3357 & 0.3347 & 0.3378 & 0.3351 & 0.3357 \\
\hline
\end{tabular}

(4) Weighted correlation degree

According to the index weight $W_{j}$ and grey correlation coefficient $\varepsilon_{i}(k)$, according to the formula 6 , we can get the weighted correlation degree of innovation performance of China's Regional Industrial Enterprises above scale, as shown in Table 5.

Table 5. Weighted relevance and ranking

\begin{tabular}{|l|c|c|}
\hline Region & Weighted relevance & Ranking \\
\hline Guangdong & 1.0000 & 1 \\
\hline Jiangsu Province & 0.6552 & 2 \\
\hline Zhejiang & 0.5232 & 3 \\
\hline Shandong & 0.4579 & 4 \\
\hline Anhui & 0.3888 & 5 \\
\hline Shanghai & 0.3811 & 6 \\
\hline Hubei & 0.3772 & 7 \\
\hline Henan Province & 0.3743 & 8 \\
\hline Hunan & 0.3739 & 9 \\
\hline Fujian & 0.3727 & 10 \\
\hline Sichuan & 0.3615 & 11 \\
\hline Hebei & 0.3601 & 12 \\
\hline Jiangxi & 0.3582 & 13 \\
\hline
\end{tabular}

\begin{tabular}{|l|l|l|}
\hline Beijing & 0.3570 & 14 \\
\hline Chongqing & 0.3567 & 15 \\
\hline Liaoning & 0.3550 & 16 \\
\hline Tianjin & 0.3528 & 17 \\
\hline Shaanxi & 0.3474 & 18 \\
\hline Shanxi & 0.3423 & 19 \\
\hline Guangxi & 0.3405 & 20 \\
\hline Yunnan & 0.3402 & 21 \\
\hline Guizhou & 0.3390 & 22 \\
\hline Jilin & 0.3384 & 23 \\
\hline Inner Mongolia & 0.3384 & 24 \\
\hline Heilongjiang & 0.3373 & 25 \\
\hline Gansu Province & 0.3358 & 26 \\
\hline Xinjiang & 0.3357 & 27 \\
\hline Ningxia & 0.3355 & 28 \\
\hline Hainan & 0.3339 & 29 \\
\hline Qinghai & 0.3336 & 30 \\
\hline
\end{tabular}

Table 5 shows that the innovation performance of Industrial Enterprises above Designated Size in Guangdong, Jiangsu, Zhejiang, Shandong and Anhui is higher than that in other regions, especially in Guangdong Province. In Gansu, Xinjiang, Ningxia, Hainan, Qinghai and other regions, the innovation performance of Industrial Enterprises above the designated size is relatively low. Most of these regions belong to the underdeveloped areas in Western China, and the innovation input and output of Industrial Enterprises above the designated size are at a low level. It is necessary to further increase investment, allocate resources as a whole, and improve the innovation performance of Industrial Enterprises above scale.

\section{Conclusion}

This paper constructs the evaluation index system of innovation performance of Industrial Enterprises above regional scale, evaluates and analyzes the innovation performance level of Industrial Enterprises above regional scale in China by using grey correlation analysis method. The results show that the level of innovation performance of Industrial Enterprises above Designated Size in China is not balanced among regions, and the gap is large. Among them, the level of innovation performance of Industrial Enterprises above Designated Size in Guangdong, Jiangsu, Zhejiang and other eastern developed regions is higher, and that of Industrial Enterprises above designated size in western underdeveloped regions is lower. Because the innovation foundation of Industrial Enterprises above scale is relatively weak in the western region, there is still a big gap in innovation capital investment and talent introduction, so the overall innovation performance level of Industrial Enterprises above scale is low.

Therefore, through the analysis of the innovation performance of China's Regional Industrial Enterprises above Designated Size, it is found that China's Industrial Enterprises above designated size are still in the stage of development, and their innovation ability is weak. It is necessary to further increase the investment in R\&D funds, and increase the strength of talent introduction. At the same time, we should constantly explore the innovation 
mode of Regional Industrial Enterprises above scale, give full play to the advantages of industry university research cooperation innovation, and improve the overall innovation level; in addition, the government should constantly optimize the innovation and growth environment of Industrial Enterprises above scale, formulate policies and support measures to promote the development of Industrial Enterprises above scale, and provide more support in policy and capital investment .At the same time, for the unbalanced development of Industrial Enterprises above the designated size among regions, we should give preferential policies to the regions with low innovation level of Industrial Enterprises above the designated size, so as to promote the healthy and rapid development of Industrial Enterprises above the designated size in underdeveloped regions, and improve the overall innovation level and core competitiveness of Industrial Enterprises above the designated size in China.

\section{Acknowledgments}

This research was financially supported by the Scientific research project of Shandong University of political science and law (No. 2020Z05B).

\section{References}

1. Yao Li. Evaluation of high quality development level of industrial economy in Central China: a case study of Hubei Province [J]. Hubei Social Sciences, 2020 (11): 55-65.

2. Li Chengshun. Evaluation of green innovation efficiency of China's industrial enterprises -- Analysis Based on panel time-varying stochastic frontier model [J]. Technical economy, 2020,39 (09): 119-125.

3. Guo Tao, Wang song, Li Panpan, Guo Zhe. Evaluation of innovation capability of China's listed shipbuilding companies from the perspective of civil military integration $[\mathrm{J}]$. Operations research and management, 2021,30 (01): 114-120.

4. Zhang Likun, Liu Xiaoli. Grey correlation analysis on Influencing Factors of urban innovation performance [J]. Research on science and technology management, 2014,34 (01): 230-233.

5. Zhang Huiru, Li Rongping. Evaluation and analysis of technological innovation capability of industrial enterprises in Hebei Province Based on grey relational evaluation method [J]. Journal of Hebei Normal University , 2010,33 (03): 48-52. 